\title{
NOTEWORTHY COLLECTIONS
}

\section{CALIFORNIA}

ACACIA DEALBATA Link. (FABACEAE). - Shasta Co., City of Redding, on a large mid-channel gravel bar in the Sacramento River approximately $0.40 \mathrm{~km} \mathrm{~S}$ of the Bonneyview Bridge, associated species include Populus fremontii, Quercus lobata, Robinia pseudoacacia, Salix lucida subsp. lasiandra, Salix exigua, Rubus discolor, Nerium oleander, Cytisus scoparius, Equisetum arvense, Carex barbarae, and Cynodon dactylon, Enterprise USGS 7.5' quadrangle, T31N R4W SE $1 / 4$ Sec. 18 , UTM 10T 0554595E 4487377N, elev. $134 \mathrm{~m}, 1$ December 2010, L. Lindstrand III, s.n. (North State Resources Herbarium ${ }^{1}$ [private], CDA); Shasta Co., on upland bluff $0.48 \mathrm{~km}$ below Shasta Dam on E side of Sacramento River, associated species include Ailanthus altissima, Quercus kelloggii, Pinus sabiniana, Robinia pseudoacacia, Arctostaphylos viscida, Cercis occidentalis, Eriodictyon californicum, Heteromeles arbutifolia, and Cytisus scoparius, also observed in nearby riparian habitat adjacent to Sacramento River associated with Salix lucida subsp. lasiandra, Salix exigua, Nerium oleander, Cephalanthus occidentalis, Fraxinus latifolia, Alnus rhombifolia, Vitis californica, and Rubus discolor, Shasta Dam USGS 7.5' quadrangle, T33N R5W NE $1 / 4$ of SW $1 / 4$ Sec. 15, UTM 10T 0548826E 4507166N, elev. 232 m, 7 December 2010, L. Lindstrand III, s.n. (North State Resources Herbarium ${ }^{1}$ [private], CDA); Shasta Co., City of Redding, on a mid-channel gravel bar in the Sacramento River approximately $0.32 \mathrm{~km} \mathrm{~S}$ of the Highway 44 Bridge, associated species include Quercus lobata, Robinia pseudoacacia, Salix lucida subsp. lasiandra, Salix exigua, Rubus discolor, Equisetum arvense, Carex barbarae, and Juncus sp., Enterprise USGS 7.5' quadrangle, T32N R4W NE $1 / 4$ of SW $1 / 4$ Sec. 31, UTM 10T 0553553E 4492622N, elevation 140 m, 7 December 2010, L. Lindstrand III, s.n. (North State Resources Herbarium $^{1}$ [private], CDA); Shasta Co., City of Redding, along rocky western shoreline of the Sacramento River approximately $0.80 \mathrm{~km} \mathrm{~S}$ of Keswick Dam, associated species include Ailanthus altissima, Quercus wislizenii, Robinia pseudoacacia, Salix lucida subsp. lasiandra, Salix exigua, Nerium oleander, Cytisus scoparius, Arctostaphylos viscida, Cercis occidentalis, Eriodictyon californicum, Ceanothus cuneatus, and Brickellia sp., Redding USGS 7.5' quadrangle, T31N R5W NW $1 / 4$ of NW $1 / 4$ Sec. 28, UTM 10T 0546918E 4495017N, elevation 152 m, 7 December 2010, L. Lindstrand III, s.n. (North State Resources Herbarium ${ }^{1}$ [private], CDA).

Previous knowledge. Acacia dealbata is native to southeastern Australia and an invasive species to California. In California the species is known to occur in the western North Coast Ranges, San Francisco Bay Region, western South Coast Ranges, and the South Coast (Hickman 1993; DiTomaso and Healy 2007). The species has also been recorded in the northern Sierra Nevada Foothills in Butte Co. (Calflora 2010). These findings represent the first records of Acacia dealbata in Shasta Co., and the northernmost-recorded extent of

${ }^{1}$ North State Resources, Inc. Herbarium, 5000 Bechelli Lane, Suite 203, Redding, CA 96002. the species in interior northern California. At the Shasta Dam site the species was first observed on 4 November 2010, when plant material was collected in the field and given a tentative identification of an unknown Acacia. Following further detailed examination, the plant was identified as Acacia dealbata. Additional plant material was collected from the site on 7 December 2010. Plant material was collected from the City of Redding sites on 1 and 7 December 2010 when the locations were first observed. Vouchers from all locations were sent to the California Department of Food and Agriculture Plant Pests Diagnostics Center for annotation, where Botany Laboratory staff confirmed the species identification.

Significance. Acacia dealbata is included in the 2007 California Invasive Plant Council Invasive Plant Inventory and assigned a "Moderate" rating (Cal-IPC 2006). These findings represent the first recorded observations of Acacia dealbata in Shasta Co., and significant (between approximately 160 to $180 \mathrm{~km}$ ) northern extensions of the known species range in interior California. Multiple age classes, fruiting individuals, and seedlings, were observed at all locations, suggesting these populations reproduce and are capable of expansion.

—LEN LindstRand III, Fisheries/Wildlife Biologist, Terrestrial Biology Program Manager, North State Resources, Inc., 5000 Bechelli Lane, Suite 203, Redding, CA 96002. lindstrand@nsrnet.com.

\section{OREGON}

MATTHIOLA INCANA (L.) W. T. Aiton (BRASSICACEAE).-Clatsop Co., $\mathrm{N}$ end of Arch Cape on sandstone cliff overlooking the Pacific Ocean, $45.82333^{\circ} \mathrm{N}$, $123.96233^{\circ} \mathrm{W}$, elev. $5 \mathrm{~m}$, with Holcus lanatus, Gaultheria shallon, Rubus, Fragaria, Lonicera, Festuca, Aira, 16 September 2008, R. R. Halse 7553 (OSC, MO).

Previous knowledge. This European native is a commonly cultivated ornamental. It has become naturalized in California and Texas on ocean cliffs and bluffs and sandy areas (Al-Shehbaz 2010.)

Significance. First report for Oregon.

BRASSICA OLERACEA L. (BRASSICACEAE).-Lane Co., along U.S. Hwy. 101 ca. $8.4 \mathrm{~m} \mathrm{~S}$ of Yachats, $44.20830^{\circ} \mathrm{N}, 124.11411^{\circ} \mathrm{W}$, elev. $15 \mathrm{~m}$, coastal bluff with Marah, Rubus, Equisetum, Vicia, Gaultheria, Heracleum, 25 May 2010, R. R. Halse 7880 (OSC, duplicates to be distributed).

Previous knowledge. This native of Europe is a commonly cultivated vegetable crop. It has become naturalized in coastal California and in the northeastern U.S. and adjacent Canada (Warwick 2010).

Significance. First report for Oregon.

SCHOENOPLECTUS CALIFORNICUS (C. A. Mey.) Soják (CYPERACEAE).--Lane Co., Siuslaw National Forest, Baker Beach area ca. $7 \mathrm{~m} \mathrm{~N}$ of Florence, $44.09333^{\circ} \mathrm{N}, 124.11920^{\circ} \mathrm{W}$, elev. $5 \mathrm{~m}$, very common in 
shallow waters around the edge of Lily Lake with Ulex, Rubus, Lysichiton, Callitriche, Oenanthe, Spiraea, stems triangular, to 3 meters tall, 9 July 2009 R. R. Halse 7719 (OSC, RSA, WTU, NY).

Previous knowledge. This native species is found in marshes from California eastward across the southern U.S. to North Carolina (Smith 2002).

Significance. First report for Oregon.

ORNITHOPUS PERPUSILLUS L. (FABACEAE).-Lane Co., Washburne State Park, N of Hecata Head, bluff above the beach, on the trail by the picnic area, in Pinus contorta woods, common, T16S, R12W, Sec. 22, 7 June 2004, K. L. Chambers 6398, determined by R. R. Halse in 2009 (OSC); same area, Carl G. Washburne Memorial State Park off of U.S. Hwy. 101 ca. $12 \mathrm{~m}$ $\mathrm{N}$ of Florence, $44.16110^{\circ} \mathrm{N}, 124.11708^{\circ} \mathrm{W}$, elev. $14 \mathrm{~m}$, weed around edges of trails with Picea, Vaccinium, Maianthemum, Gaultheria, 9 July 2009, R. R. Halse 7723 (OSC, WTU, NY, RSA, VDB); same location, common weed around parking areas with Trifolium spp., Lolium, Medicago, Vicia, 25 May 2010, R. R. Halse 7876 (OSC, MU, duplicates to be distributed).

Previous knowledge. This native of Europe is known from Pennsylvania (Rhoades and Klein 1993).

Significance. First report for Oregon.

TRIFOLIUM RETUSUM L. (FABACEAE).-Jackson Co., along State Hwy. 62 near its junction with Corey Road, southern edge of White City, $42.41491^{\circ} \mathrm{N}$, $122.85540^{\circ} \mathrm{W}$, elev. $398 \mathrm{~m}$, weedy roadside with Matricaria, Erodium, Trifolium spp., Hordeum, Vicia, Poa, 31 May 2010, R. R. Halse 7906 (OSC, MU, duplicates to be distributed).

Previous knowledge. This European native is known from California (Hrusa et al. 2002). Significance. First report for Oregon.

-Richard R. HAlse, Department of Botany and Plant Pathology, 2082 Cordley Hall, Oregon
State University, Corvallis, OR, 97331. halser@science. oregonstate.edu.

\section{Literature Cited}

Al-Shehbaz, I. A. 2010. Matthiola. Pp. 253-255 in Flora of North America Editorial Committee (eds.), Flora of North America North of Mexico, vol. 7. Oxford University Press, New York, NY.

CAL-IPC. 2006-2007, California invasive plant inventory, and update. Cal-IPC Publication 2006-02. California Invasive Plant Council, Berkeley, CA. Website: http://www.cal-ipc.org/ip/inventory/index. php [accessed 10 November 2010].

CAlflorA. 2010, The Calflora database. Berkeley, CA. Website: http://www.calflora.org/ [accessed 10 November 2010].

DiTomaso, J. M. And E. A. Healy. 2007. Weeds of California and other western states. Division of Agriculture and Natural Resources, University of California, Berkeley, CA.

HickmAN, J. C. (ed.) 1993, The Jepson manual: higher plants of California. University of California, Berkeley, CA.

Hrusa, F.; B. Ertter, A. Sanders, G. Leppig, and E. DEAN. 2002. Catalogue of non-native vascular plants occurring spontaneously in California beyond those addressed in The Jepson Manual part I. Madroño 49:61-98.

Rhoades, A. F. And W. M. Klein, JR. 1993. The vascular flora of Pennsylvania: annotated checklist and atlas. American Philosophical Society, Philadelphia, PA.

Smith, S. G. 2002. Schoenoplectus. Pp. 44-60 in Flora of North America Editorial Committee (eds.), Flora of North America North of Mexico, vol. 23. Oxford University Press, New York, NY.

WARWICK, S. I. 2010. Brassica. Pp. 419-424 in Flora of North America Editorial Committee (eds.), Flora of North America North of Mexico, vol. 7. Oxford University Press, New York, NY. 


\section{$2 \mathrm{BHL}$ Biodiversity Heritage Library}

2010. "Noteworthy Collections." Madroño; a West American journal of botany

57, 274-275. https://doi.org/10.3120/0024-9637-57.4.274.

View This Item Online: https://www.biodiversitylibrary.org/item/185636

DOI: https://doi.org/10.3120/0024-9637-57.4.274

Permalink: https://www.biodiversitylibrary.org/partpdf/169202

\section{Holding Institution}

Smithsonian Libraries

\section{Sponsored by}

Biodiversity Heritage Library

\section{Copyright \& Reuse}

Copyright Status: In Copyright. Digitized with the permission of the rights holder License: http://creativecommons.org/licenses/by-nc/3.0/ Rights: https://www.biodiversitylibrary.org/permissions/

This document was created from content at the Biodiversity Heritage Library, the world's largest open access digital library for biodiversity literature and archives. Visit BHL at https://www.biodiversitylibrary.org. 